\title{
KEJSERENS DATTER \\ I "THE KING AND THE EMPEROR" \\ Et litterært, kønsreflekteret forsøg \\ på at forstå Rabbi Nahman fra Bratslavs \\ fortelling
}

\author{
Marianne Schleicher \\ Aarhus \\ $-\infty-$
}

The secret of this tale has not yet been interpreted. What may we say of it, especially we who know nothing of hidden things? [...] The precise hidden secret which lies in each and every word and detail of this tale - and of all the tales is indeed, 'deep, deep; who can find it (Eccles. 7:24)'.'

\section{INDLEDNING}

Nahman ben Simhah fra Bratslav levede fra 1772 til i81o i Ukraine. Inden for religionshistorien er Nahman dels kendt som hasidisk messiasprætendent, dels som den hasidiske $z a d d i k$, der fra 1806 til sin død fortalte sin forholdsvis lille discipelkreds en række mystiske fortællinger. Tretten af disse fortællinger blev nedskrevet og udgivet posthumt i I8I5 af Nathan Sternhartz, Nahmans discipel og sekretær, med originaltitlen Sippurey Ma'asiyot shel Rabbi Nahman MiBratslav. ${ }^{2}$

En kønsreflekteret analyse

The King and the Emperor, ${ }^{3}$ som vil være i fokus i denne artikel, er en af disse fortællinger. The King and the Emperor er kendetegnet ved en konsekvent anvendelse af et litterært billedsprog og litterære figurer, der er tillagt køn. Nahmans anvendelse af køn er på ingen måde et enestående tilfælde i jødisk 
mystik. Sefirotsystemet, der allerede i kabbalah kan hævdes at udgøre nøglen til en forståelse af jødisk mystik, er karakteriseret ved sin opdeling i maskuline og feminine sefirot. I Sefer ha-Zohar, det kabbalistiske hovedværk, skildres f.eks. den maskuline sefirah Tif'eret og den feminine sefirah Shekhinah som selvstændige litterære figurer, hvis forening det er alt om at tilvejebringe, hvis Guds skaberværk skal opretholdes (se f.eks. Sefer ha-Zohar I, I82a). Foreningen mellem det maskuline og der feminine i sefirotsystemet avler frugtbarhed, hvorved en forståelse for de respektive sefirots køn er af afgørende betydning. Kønnethed er således ikke et ubetydeligt ej heller ukendt fænomen i jødisk mystik. Derfor kan det undre, at Nahman-forskningen ikke har tillagt Nahmans udprægede og til tider overraskende brug af $\mathrm{køn}$ i The King and the Emperor nogen væsentlig betydning, når der ofte i Nahmans systematiske værker henvises til Sefer ha-Zohar. Faktisk går Nahman-forskeren Arnold J. Band i Nahman of Bratslav - The Tales (Band) fra 1978 så vidt som til at betegne Nahmans brug af køn som betydningsløs. Band påstår, at den transvestisme, der knyttes til kejserens datter, der er den absolutte protagonist i The King and the Emperor, er et bizart, gennemgående tema, der blot afspejler Nahmans tendens til fabulationer, hans maniodepressive perioder og problematiske forhold til kvinder (f.eks. Band: 290). Mit formål med nærværende artikel vil modsat den etablerede Nahman-forsknings psykologisk biografiske tilgangsvinkel være at påvise frugtbarheden af en kønsreflekteret analyse af Nahmans fortælling The King and the Emperor ud fra den tese, at Nahmans brug af køn refererer til det kønnede sefirotsystem.

\section{En litterer metode}

Året I806 udgjorde et vigtigt skel i Nahmans liv, således som Nahman-forskeren Arthur Green understreger det i sin imponerende doktorafhandling og Nahman-biografi Tormented Master - The Life and Spiritual Quest of Rabbi Nabman of Bratslav (Green) fra 1979. 1806 var året, hvor Nahman opgav sine messiasprætentioner samtidig med, at han måtte erkende, at han ikke havde haft held til at påvirke den hasidiske verden med sine belæringer. I806 var ligeledes året, hvor Nahman fortalte sin første fortælling, hvilket efter al sandsynlighed hænger sammen med et ændret syn på menneskets forestillingsevne, som Nahman tidligere havde betragtet som permanent tilholdssted for Sitra ahra (egnt: den anden side - som regnes for de onde kræfters univers). Nahman mente efter I806, at fantasi og profeti kunne rense menneskers forestillingsevne og derefter lede dem til en erkendelse af troens og forløsningens nødvendighed. De fantastiske fortællinger udgør således den nye formidlingsform, der tages i anvendelse (jvf. Green: 340-344).

Arthur Green og Arnold J. Band er de eneste, der $\mathrm{i}$ en videnskabelig 
sammenhæng har fortolket The King and the Emperor. Deres fortolkninger udkom sidst i 1970'erne og bar stærkt præg af en biografisk tilgangsvinkel. Det skyldes de to forskeres afhængighed af Joseph Weiss. Band synes at basere hele sin indledning til sin oversættelse af Sippurey Mảasiyot på den biografiske bevidsthed (Band: 3-48). Green lægger heller ikke skjul på sin påvirkethed, når han skriver om Weiss:

...Weiss established the key guidelines for all further research in the study of Bratslav Hasidism. In his major articles he employed a method that combined the tools of intellectual history with the insights of psychoanalysis, demonstrating that in the case of so fully self-preoccupied a person as Nahman was, there can be no separation between biography and understanding of his thought. Throughout both Nahman's teachings and his stories, Weiss has shown, the central figure of concern is none other than Nahman himself. [...] it is a clarification and justification of his own life-task that is constantly at the center of Nahman's attention. This most basic insight of Weiss, though it has been somewhat criticized by Mendel Piekarz ${ }^{4}$, has not been refuted, and is also a cornerstone of our present study (Green: I7-I8).

Med al respekt for Weiss, Green og Band vil jeg dog mene, at året 1806 giver al mulig grund til påpasselighed over for den biografiske tilgangsvinkel. Samtidig med tilsidesættelsen af messiasprætentionerne valgte Nahman i 1806 en ny formidlingsform, hvor det teologiske indhold ikke kan dechifreres blot ved at henvise til de belæringer fra før I806, hvor Nahmans rolle som person var central. Fortællingerne er den primære kilde til fortællingernes teologi, og som sådan bør de analyseres. Derfor vælges en litterær og ikke en biografisk metode i denne artikel.

\section{En litterer, kønsreflekteret analysemetode}

Som artiklens titel anfører, vil fokus rettes mod kejserens datter i The King and the Emperor, hvor hun er den dominerende litterære figur. Min opmærksomhed vil blive rettet mod tre slags litterære fænomener, henholdsvis genbrug af religiøst billedsprog, billedsprogets grad af åbenhed og de litterære figurers aktivitetsgrad og værdiladninger set i forhold til deres køn, da disse tre fænomener er afgørende for udlægningen af hende.

Genbrug af det religiøse billedsprog synes at være en vigtig bestanddel i religiøse retningers udvikling, ${ }^{5}$ hvor de i kraft af billedsprogets referencer bl.a. kan placere sig selv i en religiøs tradition samtidig med, at de pga. traditionens berydning for tilhørerne kan legitimere deres nye budskab.

Inkorporationen af religiøst billedsprog fra tidligere traditioner kan bl.a. muliggøres gennem et åbent billedsprog (jvf. Nielsen 1985). Billedsprogets 
grad af åbenhed afhænger af, hvorvidt tilhøreren/læseren opfordres til at tænke to tanker samtidigt - en opfordring, der muliggøres dels af billedets referencer til en kendt og umiddelbar kontekst, dels af billedets fortidige anvendelse og konnotationer. ${ }^{6}$ I forbindelse med kejserens datter vil jeg forsøge at påvise, at hun som litterær figur indeholder referencer til litterære beskrivelser af Guds tilstedeværelse, f.eks. som den sky- og ildsøjle i Tanakh'en, der ledte folket (Ex. I3,2I-22), og som den selvstændige, litterære figur i kabbalah, der i kraft af sin funktion som den tiende sefirah Shekbinah udøver Guds dom eller barmhjertighed alt efter folkets adfærd (se Sefer ha-Zohar I, ta og Scholem 1953). Referencer til disse fortidige, litterære fænomener bliver, som jeg vil vise, knyttet til kejserens datter, samtidig med at kejserens datter beskrives yderst tvetydigt med det resultat, at tilhøreren/læeseren for at kunne nå til en forståelse må engagere sig $\mathrm{i}$ billedsproget og tænke dels på kejserdatterens litterære/religiøse ophav, dels på hendes placering i Nahmans fortælling. At tilhøreren/læseren må tænke to tanker samtidigt, kendetegner det åbne billedsprog. ${ }^{7}$

Den billedsproglige bevidsthed i nærværende projekt implicerer imidlertid et fokus på køn. Artiklens analyse vil fokusere på de litterære billeder og figurers værdiladninger i forhold til køn og aktivitetgrad, da det er min tese, at dette fokus leder til at kunne afdække, hvilken teologi der søges formidlet. Skildres kønnene atypisk, synes de enten at være repræsentanter for en adfærd, der forhindrer Guds intention med skabelsen, i.e. liv, eller repræsentanter for den straf, som Gud må udøve for at få udryddet ondskaben. Kønsskildringerne fungerer som markører for Nahmans sympati og antipati, når litterære figurer påhæftes typiske eller atypiske karakteristika, og de hjælper således tilhøreren/læseren til et indblik i Nahmans religiøse budskab.

En ideologikritisk anvendelse af begrebet "det andet" (jvf. Simone de Beauvoir, Luce Irigaray og Elliot R. Wolfson) ligger til grund for min belysning af Nahmans brug af køn. "Det andet" er i en litterær-analytisk sammenhæng et begreb, der kan påhæftes de litterære figurer, der forbliver umælende i det litterære værk, og som kun får præciseret deres identitet gennem andres formuleringer og handlinger. De tilkendes ingen subjektidentitet men forbliver objekter for de litterære figurer, der besidder taleevnen. Figurer, der tilkendes sproglige reaktioner i et litterært værk, er i stand til at påvirke det litterære værks udvikling, og som sådan besidder de en vis magt på fortælleplanet. ${ }^{8}$ Fordi det kønnede sefirotsystem er så afgørende for en forståelse af jødisk mystik, er det min tese, at de figurer, der fungerer som talerør for Nahmans budskab, dels er udstyrret med taleevnen og dermed muligheden for selvrepræsentation, dels er afhængige af kønsopfattelser, der refererer til den ideelle balance i sefirotsystemet. Den ideelle balance i sefirotsystemet afspejles, 
når de maskuline sefirot er aktive og ydende ved at sende de guddommelige energier, der flyder i systemet, videre til de feminine sefirot, der forholder sig passive for at kunne være receptive over for disse energier. Kejserens datter, der $\mathrm{i}$ The King and the Emperor imidlertid bevæger sig fra passivitet til aktivitet, fra sympatisk tilbagetrukkenhed til morderisk aktivitet og fra feminin til maskulin adfærd, udgør en udfordring for min tese, der fører til denne artikels afgørende problemformulering: Hvordan kan kejserens datter både fungere som Nahmans protagonist og dermed talerør, når hun ved sine handlinger $\mathrm{i}$ løbet af fortællingen afviger fundamentalt fra den ideelle rolle, som tilskrives feminine figurer i jødisk mystik?

\section{Analyse}

Analysen af The King and the Emperor vil være baseret pa en opdeling i flere afsnit, end der forekommer i fortællingen, som den præsenteres i Bands oversættelse. Det skyldes, at kejserdatterens møde med fortællingens forskellige mænd fremstår som midlertidige, afrundede forløb med selvstændig betydning for den endelige fortolkning. Forud for min analyse af de forskellige afsnit vil en parafrase af afsnittets indhold og udvikling blive givet. Parafrasen angives med kursiv.

Forhistorien (Band: 67,I-69,12)

Plaget af deres barnloshed beveger en kejser og en konge sig hver for sig ud i verden for at finde en losning $p a$ deres problem. De modes tilfaldigt på en kro. Forst legger de merke til hinandens royale status, dernost nàr de frem til, at de begge kamper med barnloshed. De aftaler, i tilfalde af at de begge far et barn, den ene en pige, den anden en dreng, at der skal arrangeres et agteskab mellem dem. Efter modet på kroen drager kejseren og kongen hver til sit. Kejseren fär en datter og kongen en søn, men loftet glemmes. Senere fär bornene tilfeldigvis den samme lover, og hos ham forelsker kejserens datter og kongens søn sig $i$ hinanden. De indgär et mere eller mindre hemmeligt agteskab, og kejserens datter fär en ring som symbol derpå. Uvidende om agteskabet beordrer fadrene imidlertid bornene hjem, hvorved de adskilt fra hinanden mister sprog og helbred pga. langsel. Fadrene forsoger alt for at andre deres tilstand, men uden held. Kongen spørger kongesønnens tjener, der var med hos lareren, om han har en forklaring, hvorefter tjeneren fortaller om agteskabet. Kongen husker på det gamle lofte og skriver et brev til kejseren for at minde ham derom. Kejseren sender derefter meget modstrabende bud efter 
kongesønnen for at undersøge, om kongesønnen nu også er $i$ stand til at regere hans rige. I kejserens palads modes de to elskende tilfaldigt, og fordi kejserens modvilje er så abenlys, enes de om at flygte til havs. Under flugten logger kejserens datter og kongesønnen til ved en skov for at overnatte dér. I lobet af natten lader de ringen vandre mellem sig, og kongesonnen placerer den til sidst ved siden af kejserens datter. Neste morgen pà vej ned til skibet kommer kejserens datter $i$ tanke om, at de har glemt ringen. Hun sender kongesønnen tilbage efter den, men han kan ikke finde den og farer vild. Da han ikke kommer tilbage, drager bun ind $i$ skoven for at finde ham, men her farer ogsä bun vild. Kongesønnen när til et beboet omräde og ser ingen anden udvej end at blive tjener. Kejserens datter valger at sla sig ned ved kysten med dens treer $i$ tilfalde af, at der skulle komme nogle forbipasserende. Hun beslutter at lade sig nere af traernes frugter, og om natten kravler bun op $i$ et af dem for at vere beskyttet mod dyrene.

Forhistorien indledes med et forløb, hvor rammen udgøres af tilfældet. Situationen, hvor tilfældet lader kongen og kejseren mødes, afslører, at begge noterer sig den andens status for først derefter at erkende, at de begge plages af samme problem, i.e. barnløshed. For royale personer er barnløshed et dobbelt problem, idet både videreførelse af slægten og overdragelse af status er truet. Som udtryk for deres brændende ønske om forlængelse af slægt og status sætter de selvsamme status på spil ved at indgå et løfte, hvor begge risikerer, at den delvist går over på andre hænder. Barnløshed er resultatet af ufrugtbarhed, der traditionelt $\mathrm{i}$ israelitisk-jødisk religion ses om ikke som Guds straf, så da som noget, der er totalt i Guds magt. ${ }^{9}$ Teksten er skrevet til et jødisk publikum med kendskab til barnløshedens fortolkningshistorie, og den jødiske tilhører/læeser vil højst sandsynligt, da kejseren og kongen vælger at indgå et løfte om deres to ønskebørns forening, lægge til fortællingen, at eventuelt løftebrud længere fremme i fortællingen vil blive straffet af Gud. ${ }^{10}$ Det følger efter løftet, at både kejserens og kongens hustru nedkommer med et barn, men den årsagssammenhæng synes de nybagte fædre langt fra at kunne se. Begge glemmer løftet, og denne glemsomhed forekommer langt fra tilfældig. Specielt kejseren har grund til at glemme løftet, idet kejserens titel er mere prestigefuld end kongens, og idet der for kejseren for alvor er fare for magttab, da det bliver klart, at han "kun" har fået en datter. Det betyder jo, at "kun" en konges søn som mand ved giftermål med kejserens datter er selvskrevet til at regere over kejserens rige. Derfor virker specielt kejserens glemsomhed som beskyttelse af sin egen slægts status.

Tilfældet vil imidlertid andet end kejseren, og glemsomhed kan ikke forhindre; at børnene selv indfrier løftet, da de tilfældigt mødes hos læreren, 
hvor kongens søn giver kejserens datter en ring som symbol på deres forening og deres hemmelige ægteskab. Fædrene manifesterer imidlertid deres vilje og beordrer børnene hjem. Adskillelsen fører til, at de nu halvvoksne børn bliver ude af stand til at fungere; de mister sprog og helbred. Først da de elskende tilfældigt mødes i kejserens palads, genvinder de sprog og dermed handlekraft og beslutter at flygte. Denne flugt bliver fædrenes straf. Løftet, der i sin tid blev indgået ved et tilfældigt møde i håb om at undgå barnløshed, som af tilhøreren/læseren associeres med Guds straf, blev glemt med vilje, fordi magtbegæret var for stort, og fordi det for kejseren og kongen var en trussel mod deres royale position. Men trods det, at fædrene to gange med deres viljes magt kunne afbøje tilfældets kurs, forhindrer det ikke tilfældet $i$ at dukke op en tredie gang og straffe fædrene dér, hvor de er allermest sårbare ved at lade børnene flygte. Tilfældet har med andre ord udført den straf, som tilhøreren/læseren kunne forvente udført af Gud.

Om natten i skoven - et sted for erkendelse, hvor alting synes at kunne ske $^{11}$, - lader de elskende ringen, som er symbolet på deres hemmelige ægteskab, vandre mellem sig. Et meget smukt billede, hvor ringens vandring væver de to endnu tættere sammen, idet ringen som tegn kommer i berøring med de to personer, som er bestanddelene $\mathrm{i}$ tegnets indhold. Ringen som symbol står styrket efter natten, og derfor virker det efterfølgende tab af ringen så meget desto mere katastrofalt. Kærligheden synes ikke at have taget skade, idet de elskendes søgen efter hinanden er næste skridt i fortællingens udvikling. Men glemsomheden fører til adskillelse, hvilket er en meget logisk konsekvens, når man tager $\mathrm{i}$ betragtning, at ringen symboliserede forening. Det bemærkelsesværdige er, at første gang, at adskillelse blev påtvunget de elskende, var, $\mathrm{da}$ fædrene manifesterede deres egensindige vilje. Denne gang er det viljens diametrale modsætning, i.e. glemsomhed, forsømmelse og manglende engagement i, hvad der sker omkring dem, der bevirker adskillelsen. Således sidestilles egensindig vilje med glemsomhed og manglende engagement, hvor begge modsætninger bliver negativt konnoterede.

Det manglende engagement er karakteristisk for kongesønnens reaktion på adskillelsen, omend reaktionen fremstår som mere eller mindre nødvendig. En mand forbindes med og forventes i den virkelige verden at udvise handle kraft, men om kongesønnen står der, at han ikke kunne gøre noget, så han blev tjener (Band: 69,5-6). Som tjener går kongesønnen for det første under sin stand, hvilket i et patriarkalsk univers som det israelitisk-jødiske er meget negativt. For det andet udfører en tjener intet på eget initiativ og sammen med udsagnet om, at han ikke kunne gøre noget, etablerer han sig i en meget feminin rolle, idet passivitet associeres med det kvindelige. Som mænd forbindes med handlekraft, forbindes kvinder med det at modtage. Derfor har 
kongesønnen placeret sig selv i et dilemma, hvor han hverken kan opføre sig som mand eller kvinde, fordi hans køn afskærer ham fra at modtage. Med andre ord har det manglende engagement og initiativ og den hierarkiske deroute konnoteret ham med negativ passivitet - negativ, fordi hans situation er ufrugtbar, når han ikke aktivt kan yde. Endelig understreges kongesønnens passivitet også med det faktum, at han forsvinder ud af fortællingen for først igen at dukke op til allersidst.

Fra og med Band: 69,6 er det kejserens datter alene, der bliver fortællingens centrale fokus. Den måde, hvorpå hun reagerer på adskillelsen, står i skarp kontrast til kongesønnens, idet hun har en plan. Hun vælger for det første et opholdssted, hvor eventuelle forbipasserende kan se hende. På den måde åbner hun op for, at andre figurer kan bevæge fortællingen og hende selv $i$ en ny retning. For det andet lader hun sig nære af de frugter, som naturen byder hende. Med andre ord modtager hun tro mod sin kvindelige natur. For det tredie søger hun om natten beskyttelse mod dyrene i et træ. Det er en handling, der pga. ordene "et træ" og "dyrene" får enhver læser med kendskab til kabbalah til at associere til sefirotsystemet, der ofte beskrives som et træ, og til Shekhinah, den tiende sefirah, der trækker sig tilbage til sin plads i sefirotsystemet for at lade sig nære af de øvre sefirot; en plads, hvor både hun selv og hendes dyd samtidig er beskyttet imod Samael, der i Sefer ha-Zohar betegnes som et dyr (Se f.eks. Sefer ha-Zohar II, 34a-35b). Idet Nahman havde kendskab til kabbalah, kan det formodes, at han med overlæg her har konnoteret kejserens datter med træk fra Shekhinah. Beskrivelsen af hende er yderst positiv, idet hun åbner op for hjælp, hun modtager som en kvinde bør, og endelig vogter hun sin dyd imod synden, hvilket er meget vigtigt, idet hun er adskilt fra sin udkårne og dermed sårbar over for andre mænd. Kejserens datter beskrives som passiv i en konstruktiv forstand, selvom det vel kan lyde som en selvmodsigelse. Men i jødisk mystik, når det drejer sig om Shekhinah, er hendes receptive og passive rolle altafgørende for, om de befrugtende energistrømme fra de øvre sefirot kan finde rum og lejre sig $\mathrm{i}$ hende og således skabe liv og frugtbarhed på jorden og blandt mennesker. Deri ligger det konstruktive ved passiviteten. Fordi Nahman anvender litterære billeder fra kabbalah i sin beskrivelse af kejserens datter, har han dels åbnet op for en ny forståelse af kejserens datter som litterær figur ved at konnotere hende med træk fra Shekhinah, og han har dels vakt tilhørerens/læserens sympati for hende.

Mødet med købmandssønnen (Band: 69,13-7I,II)

Andet afsnit indledes med en prosentation af en købmandssøn, der øns$k e r$ at $g a ̊ i$ sin faders fodspor som alternativ til lediggang. Faderen imodekommer sønnens ønske, og sønnen klarer sig glimrende. Til havs 
passerer købmandssønnen det sted, bvor kejserens datter valgte at slå sig ned. Somendene synes, det ligner beboelse, og de onsker at komme narmere men skuffes, da de finder ud af, at det, som de opfattede som beboelse, kun er traer. Købmandssønnen er imidlertid mere klarsynet og ser noget, der har skikkelse af en person (Band: 69,30). Tvivlen overfalder ham, og han søger stotte for sit syn hos sømandene, der nu også ser noget, der har skikkelse af en person i toppen af et af treerne. De beslutter at sende en mand ind for at se normere efter, og han vender tilbage med meddelelsen om, at det ér en person, der sidder deroppe. Kobmandssønnen kommanderer kejserens datter ned fra traet, og bun stiller diverse betingelser for at gå ombord på købmandssønnens skib. Hun fär ham til at love, at han ikke vil rore hende eller sporge bende ud om hendes identitet, forend de vender hjem og agter hinanden pà lovlig vis. Under hendes ophold på skibet gleder købmandssønen sigover, at han har modt bende, fordi hun kan spille på musikinstrumenter og behersker mange sprog. Da bans hjem er i sigte, fortaller bun ham, at det er behørigt, idet hun er en vigtig kvinde, at han forbereder sin fader, slagtninge og venner på hendes ankomst, så de kan byde hende velkommen. Han accepterer, idet hun lokker med at afslore sin identitet. Hendes neste skridt er at beordre købmandssønnen til at drikke skibets besetning fuld, igen med en henvisning til hendes bøje rang. Købmandssønnen gør alt, bvad hun befaler; dette udnytter bun til fulde, stjeler skibet og stikker af til havs. Købmandssønnen bliver bortvist fra sit hjem af sin rasende fader til et liv som flygtning på vandring.

Beskrivelsen af købmandssønnen, der meget plausibelt ønsker at gå i sin faders fodspor som alternativ til lediggang, er positiv. Købmandssønnen får trods tvivl øje på kejserens datter oppe i et af træerne. Denne passage virker lidt karikerende, idet spørgsmålet om, hvorvidt der måske sidder et menneske i toppen af et træ, umiddelbart synes betydningsløst. Men denne karikatur og vendingen: "skikkelse af en person" er sandsynligvis markører, der har til formål at associere kejserens datter med Menneskesønnen fra Daniel 7,I3f ved at beskrive hende på lignende vis. Hvis det er tilfældet, understreger Nahman endnu engang, at der ikke er tale om et almindeligt menneske oppe i dette træ, der heller ikke er et normalt træ, jvf. træets konnotationer $i$ det foregående afsnit til sefirotsystemet. Kejserens datter er, indtil hun bliver kommanderet ned fra træet, tillagt adskillige positive træk, men med købmandssønnens befaling ændrer kejserens datter som litterær figur natur fra at have været passiv til at gribe til handling på yderst aktiv vis. Hun forlader - vel under diverse betingelser - det træ, som udgjorde beskyttelse for hendes dyd, og som med reference til sefirotsystemet nærede hende med guddommelige energier fra 
de øvre sefirot. I dette afsnit følger derefter en beskrivelse af kejserens datter, hvor hun er aktiv og moralsk set tillagt negative træk, hvilket indikerer, at kejserens datter som litterær figur har undergået sin første metamorfose. Hun har forladt sin passive rolle og sin plads i sefirotsystemet og har taget midler i brug, der ikke skyr falske løfter, tyveri og det at bringe andre i ulykke. ${ }^{12}$ Denne metamorfose betyder imidlertid ikke, at hun ikke længere er forbundet til det guddommelige. At Nahman tillægger hende færdigheder inden for sprog og musik kan være hans måde at fastholde tilhørerens/læeserens sympati for hende, idet musik og sprog $\mathrm{i}$ hasidismen er udtryk for indsigt $\mathrm{i}$ guddommelige redskaber, hvormed ondskaben kan bekæmpes. ${ }^{13}$

Modet med den ugifte konge (Band: 7I,I2 - 72,35)

Et skib sejler forbi en kyststrekning. Det er kejserens datter, der styrer skibet, mens kapitlets bifigur, en konge, sidder $i$ sit palads inde ved kysten og ser på. Denne konge betvivler, hvad han ser. Tvivlen skyldes, at skibet ingen àrer eller besatning har. Han lader derfor sine undersåtter bekrafte sit syn. Efter undersatternes bekraftelse af synet forbindrer han kejserens datter $i$ at sejle forbi og beordrer hende ind til kysten. Her stiller kejserens datter endnu engang en fremmed et lovligt agteskab $i$ sigte under betingelse af, at han hverken rorer hende eller besigtiger hendes skib for brylluppet. Når brylluppet så har fundet sted, vil alle kunne se, hvor velstående hun er. Den ugifte konge accepterer disse betingelser. Han inviterer alverden til sit og kejserdatterens bryllup og bygger paladser til sin kommende brud, selvom bun ikke bryder sig om paladser. Hun kraver overraskende at fà elleve hofdamer. De er dotre af adelen, de far hver sit palads men samles hos kejserens datter for at spille musik og spil med hende. Som hofdamer skal de selvfolgelig adlyde deres frue, så da kejserens datter giver udtryk for onsket om at sejle sammen med dem, folger de trop. De leger ombord, og kejserens datter serverer vin for dem, så de bliver fulde og falder i søvn. Dette udnytter kejserens datter, hun stikker af til søs med sit skib og sine elleve hofdamer. Kongen og hans mond frygter i forste omgang, at kejserdatterens skib er blevet stjallet, og gruer for hendes vrede og for, at hun måske skal tro, at kongen har givet hendes skib vak. Kongen finder imidlertid ud af, at bade kejserens datter og hendes elleve hofdamer er forsuundet. Hofdamernes adelige fedre bebrejder kongen dotrenes forsvinden, og $i$ deres raseri detroniserer og eksilerer de den ugifte konge.

Afsnittet indledes med beskrivelsen af en situation, der har mange lighedspunkter med det foregående afsnit: Ligheden er først og fremmest, at et skib sejler forbi en kyststrækning, hvor en person har valgt at slå sig ned for at 
kunne komme i kontakt med eventuelle forbipasserende. Forskellene mellem de to kapitler markerer imidlertid, at fortællingen har ændret og udviklet sig. Den væsentligste forskel er, at kejserens datter har forladt sin passive position i det træ, der udgjorde hendes beskyttelse, og at hun nu er i bevægelse. Den ugifte konges ordre om, at hun skal lægge til ved hans palads understreger, at kejserens datter på ingen måde er beskyttet. Kejserens datter må selv vise snarrådighed, hvis hun skal vare tro mod sin elskede og beskytte den dyd, som blev vogtet oppe i træet. I tilfælde af at tilhøreren/læseren skulle have mistet sympatien for kejserens datter efter hendes seneste ugerninger, så giver beskrivelsen af skibet uden årer dog anledning til håb, da et sådant kendes fra beretningen om Noas ark (Gen. 6-8), der skulle sikre menneskehedens overlevelse. Samtidig udtaler hun sympatisk, at hun ikke er interesseret i paladser. Det er en beroligelse, som dog meget hurtigt må stå for fald, da hun igen med diverse betingelser stiller den ugifte konge ægteskab i sigte, samtidig med at hun henviser til sin høje rang, hvilket står i modsætningsforhold til hendes manglende interesse for paladser og for hendes egen faders fokus på status. Tilhøreren/læseren har grund til at frygte, at hun har glemt sit hemmelige ægteskab med kongesønnen, og at hendes dyd og værdinormer dermed er truede. Den ugifte konge gør alt, hvad kejserens datter befaler, og da hun kræver elleve hofdamer, henter han dem fra adelen. Man kan gisne meget om, hvorfor hun beordrer de elleve hofdamer. Hofdamerne er af adelig herkomst og har kendskab til musik og sprog. Musik og sprog er som nævnt i Bratslavtraditionen (se note $\mathrm{x} 3$ ) et symbol på guddommelig indsigt, og med denne indsigt og deres rang kan de muligvis udgøre en ressource for kejserens datter på længere sigt. Tallet elleve har ingen symbolværdi i israelitisk-jødisk religion, men hvis man lægger kejserens datter til de elleve, så fås tallet tolv, som $\mathrm{i}$ israelitisk-jødisk religion har klare referencer til Israels tolv stammer. Hvis den tese holder, bliver kejserdatterens efterfølgende bortførelse af de elleve hofdamer mere forståelig, og bortførelse kan i så fald og sammen med referencen til Noas ark ændre betydning til befrielse. Det er det imidlertid for tidligt at gisne om, og det er først og fremmest vigtigt at notere sig, at kejserens datter bortfører elleve kvinder. Bortførelse af kvinder har altid indeholdt en trussel mod kvinders dyd, fordi de er blevet fjernet fra de fædre eller ægtemænd, som burde have vogtet den..$^{14}$ I Nahmans fortælling er det en kvinde, som udfører den gerning, der har sexuelle undertoner. Grunden til, at jeg mener, at netop dette er vigtigt at notere sig, er, at tilhøreren/læseren $i$ kejserdatterens møde med den ugifte konge får udvidet sit negative billede af kejserens datter, idet hun igen henviser til status og opstiller falske løfter om ægteskab, men derudover også drikker hofdamerne fulde for at bortføre dem til en situation, som har homosexuelle undertoner, og samtidig medfører, at en 
uskyldig og oprigtigt bekymret konge detroniseres og eksileres. Den første tvivl om kejserdatterens "gender" ${ }^{15}$ og værdiladning er blevet bragt ind i fortællingen.

\section{Mødet med røverne (Band: 73,I - 74,13)}

Da hofdamerne genvinder deres bevidsthed, fortsetter de deres leg med kejserens datter uvidende om, at skibet har veret undervejs på havet $i$ et stykke tid. Hofdamerne udstyres nu for forste gang i fortallingen med evnen til tale. De udtrykker ønske om at vende hjem, men kejserens datter afviser med den begrundelse, at hun vil blive ombord lidt langere. Et uvejr dukker op, og hofdamerne udtrykker endnu engang onske om at vende bjem. Kejserens datter fortaller dem nu, at skibet har forladt kysten for lange siden. Da hofdamerne sporger, hvorfor hun har ladet dette ske, svarer bun, at bun frygtede, at uvejret ville odelagge skibet (sikkert indforstået det fortøjrede skib). Sammen fortsatter de deres fard og udover musik. De passerer et palads, og hofdamerne onsker at lagge til. Kejserens datter afuiser for tredie gang og fortaller desuden, at hun fortrod, at bun $i$ sin tid havde lagt til ved den ugifte konges palads. Senere kommer de til noget, der ligner en $\emptyset$, hvor der er tolv rovere, der ønsker at drabe kvinderne. Kejserens datter beder om at tale med den storste blandt røverne for at udspørge ham om deres profession. Han svarer hende, at de er rovere. Hun svarer igen, at også hun og bofdamerne er rovere; den eneste forskel er blot, at mandene er rovere i kraft af magt, mens hun og hofdamerne er det $i$ kraft af deres visdom, idet de behersker diverse sprog og musikinstrumenter. Kejserens datter udnytter rovernes magtbegar, idet bun forsoger at redde sit eget og besatningens liv ved at foreslå rovernes leder, at alle fireogtyve skal slä sig sammen i agteskab, så roverne kan fä del i kvindernes rigdomme. De besigtiger hinandens rigdomme, og tilfredse aftaler de, at ikke alle skal giftes på én gang, men at én røver skal valge sig én kvinde, således at der afholdes ét bryllup ad gangen. Hun forteller roverne, at hun vil servere en vin, som bun har gemt ombord på skibet med henblik på den dag, hvor Herren vil udvalge hendes udkärne. Hun serverer vinen i tolv bagre, og hver og en af roverne drikker for alle tolv, så de bliver fulde og falder om. Kejserens datter beordrer nu hofdamerne til at slagte roverne. Hofdamerne adlyder og bemagtiger sig bagefter det guld og de edelstene, der er blandt rovernes rigdomme, og lesser det ombord på kejserdatterens skib. Inden de drager videre, beslutter de ikke langere at klade sig som kvinder men at sy sig mandsdragter.

I denne del af fortællingen er hofdamerne, da de igen kommer til bevidsthed, udstyret med evnen til at tale og har hermed faet mulighed for som enhver 
anden talende litterær figur at påvirke fortællingens udvikling. De giver flere gange udtryk for, at de ønsker at vende hjem, men hver gang ønsket udtrykkes, holder kejserens datter dem hen med egne ord, en løgn og forklaringen om, at hun fortryder begivenheden, der bragte dem sammen. Kejserdatterens overlegenhed slås her fast, idet hun umyndiggør elleve talende figurer ved ikke at lytte til deres ord. Umyndiggørelsen betyder imidlertid ikke, at hun løber fra sit ansvar som hofdamernes overordnede. I det følgende understreges fællesskabet ved, at kejserens datter og de elleve hofdamer betegnes som "kvinderne" og dermed som én gruppe. Denne gruppe har i kraft af deres køn nu et fælles problem, idet de står ansigt til ansigt med de tolv mandlige røvere, som har til hensigt at dræbe dem. Røverne befinder sig på noget, der ligner en ø. Denne formulering kan være en henvisning til Sitra ahras residens (Se Sefer ha-Zohar II, 34a-35b) og kan således indikere, at røverne er repræsentanter for ondskab. Men det kan også blot være en formulering, der hjælper Nahman til at skabe et univers for fortællingen, der ikke er i umiddelbar forbindelse med den virkelige verden. Kejserens datter kræver på denne $\emptyset$ at tale med røvernes leder og viser dermed sit mod til at konfrontere sig med den stærkeste. Hun får understreget forskellen på de to grupper med sin tale om røvere med magt og røvere med visdom. Måske er det kun et ordspil, eller måske får Nahman hermed sagt, at netop den visdom, som kejserens datter besidder, er langt stærkere end rå magt. Udtalelsen kan rumme et håb for de hasidiske læsere/ tilhørere, fordi hendes visdom, der finder sit udtryk i musik og sprog, i hasidismen er indsigt i Guds vilje, og dermed loves hasid'erne en fremtid, hvor de vil være immune over for magtanvendelse. Derefter stiller kejserens datter endnu en gang falske løfter om ægteskab i sigte og lokker ved at tilbyde de magtbegærlige røvere adgang til kvindernes rigdomme, som ud over mammon også suppleres af musik- og sprogkyndighed. Kejserens datter gør igen brug af sin vin til at drikke røverne fulde og misbruger i den forbindelse Guds navn, hvilket absolut må betegnes som en synd i israelitisk-jødisk religion (Ex. 20,7). Men ikke nok med det; da røverne er drukket fra sans og samling, beordrer hun sine hofdamer til at slagte dem. De stjæler røvernes kostbareste ejendomme, og endelig skjuler kvinderne det køn, Gud gav dem, og klæder sig som mænd.

To planer i fortællingen synes at kunne skimtes tydeligere i dette afsnit - to planer, som ubemærket har ligget og konstrueret tilhørerens/læserens ambivalens over for kejserens datter, siden hun blev kommanderet ned fra træet. På ét plan har kejserens datter vist sig fra sin værste side over for adskillige uskyldige personer, og i mødet med røverne, der havde mord som intention, stod hun ikke til side for at gengælde intentionen med virkeliggørelse. Hun har nu også mord på samvittigheden. Men det er netop disse ugerninger, der muliggør, at 
kvinderne kan sejle videre efter den plan, som tilhøreren/læeseren endnu ikke ved, hvor skal føre hen. Siden kejserens datter blev tvunget til at forlade det træ, der ydede hende beskyttelse, har hun været nødsaget til - noget, som tilhøreren/læseren kun kan bifalde, idet kejserens datter deler træk med Shekhinah - at beskytte sig selv. Men denne beskyttelse er blevet udgjort af gerninger, der kunne betragtes som værende onde. Selvbeskyttelsen er fortællingens andet plan.

Denne dobbelthed hjælper desuden tilhørere/læasere med kendskab til kabbalah, specielt til Sefer ha-Zohar, til forståelse og til at se lighedspunkterne med Shekhinah. I Nahmans fortælling er kejserens datter som litterær figur konnoteret med træk fra Shekhinah samtidig med, at hun udfører onde gerninger. I Sefer ha-Zohar er den beskyttende ondskab adskilt fra Shekhinah og i stedet manifesteret i en selvstændig figur, nemlig Lilith, som dér betegnes som den beskyttende skal (kelippah) omkring kernen; som Shekhinahs tjenestepige; som det beskyttende brønddæksel etc. (Se Sefer ha-Zohar III, 69a og I, I5Ib-I52a). Men at den beskyttende ondskab optræder som en selvstændig figur, betyder ikke, at Sefer ha-Zohar ikke er opmærksom på, at Shekhinah - indbegrebet af den gode, dydige, moderlige kvinde - og Lilith den inkarnerede synd - har samme rod, nemlig funktionen som folkets rettesnor, der med en ligelig fordeling af dom (jvf. sefiratien Din) og barmhjertighed (jvf. sefirabien Hesed), der strømmer til den tiende sefirah fra det øvre system, skal retlede og bringe frugtbarhed til Israels folk. Hele ambivalensen i Nahmans fortælling over for kejserens datter, tror jeg, er en markør, der skal gøre tilhøreren/læseren opmærksom på den nødvendige dobbelthed. "Gender"-skiftet, der finder sted sidst i derte afsnit, er ligeledes led i den nødvendige dobbelthed, idet kvindernes udvendige forvandling til mænd udgør en beskyttelse, således at de ikke længere trues på deres køn. At kejserdatterens ydre metamorfose til mand desuden medfører et positivt syn på aktiviteten, vil jeg vende tilbage til.

Modet med den skaldede kronprins og hans besatning (Band: 74,I4 - 77,4)

En ung mand - i dette tilfalde en kronprins - udtrykker ønske over for sin fader om at drage til søs for at opnå erfaring. Onsket imodekommes, men faderens velvilje gengaldes ikke med en oprigtig indsats. Kronprinsen drager afsted med sin bustru og sine undersattter for blot $i$ kadhed og frivolitet at lobe halvnogne rundt på et skib. I den mundering klatrer kronprinsen op i skibets mast. Kejserens datter og hendes elleve hofdamer nermer sig kronprinsens skib og er $i$ begyndelsen bange for, at det fremmede skibs besatning er rovere. Da hun imidlertid ser, at de lober legende rundt, praler hun over for sine hofdamer med, at hun kan valte 
den "skaldepande" ned fra masten - en hentydning til kronprinsens skaldede isse. Hun forklarer, at bun har en linse, og med den er det muligt at velte ham ned. Hun venter dog, til han er nået belt til tops, således at han vil falde $i$ havet og ikke ned på dakket. Besatningen bliver oprorte over kronprinsens fald - ikke så meget pga. kronprinsens sandsynlige dod, men mere fordi den frygter for sin egen skabne, frygter at stå ansigt til ansigt med den gamle konges sorg over tabet af sonnen, hvis den vender tilbage. Derfor beslutter besetningen at nerme sig kejserdatterens skib i håb om, at der er en lage ombord, der kan rädgive den. Kejserens datter - som kronprinsens besetning tror er en mand pga. kvindernes klededragt-beordrer dem til at hale kronprinsen op af havet. Han (bun) foler hans puls og forudsiger, at hans hjerne vil vare brondt. De åbner op til hjernen og ser til deres forbavselse, at han (hun) har ret. Den afdøde kronprins' besatning beder kejserens datter om at blive den gamle konges lage og lokker med status. Han (bun) afviser og forteller desuden, at han (bun) ikke er lege men blot ved sådanne ting. Kronprinsens besatning frygter straffen, der venter, hvis den vender hjem, så den valger at sejle videre sammen med kejserdatterens skib. Kronprinsens undersaitter finder idéen om, at deres kronprinsesse skal gifte sig med legen (kejserens datter) tiltalende, fordi han (hun) er sä viis. De er endda parate til at drabe deres gamle konge for at gøre plads til lagen. Dog er de flove over at foreslå agteskabet til deres kronprinsesse, men bun viser sig at vere meget interesseret. Det eneste, bun frygter, er landets reaktion; om det nu ogsä vil acceptere lagen (kejserens datter) som konge. En rakke banketter afholdes under deres sejllads, fordi alle, der ønsker dette agteskab, häber på, at alkoholens indvirkninger kan lette samtalerne om dette emne. Da samtalen falder på agteskab, trakker kejserens datter sin for tilhoreren/laseren nu så velkendte vin op for at få indblik i de forskelliges intentioner. Agteskabsplanerne kommer frem og logens (kejserdatterens) respons skal åbenbart tages som hans (hendes) billigelse; $i$ hvert fald når kronprinsessen og undersåtterne $i$ det folgende trods deres flowhed frem til, at det er et sådant agteskab, de onsker, hvilket resulterer $i$, at alle vender tilbage til kronprinsessens land, bvor de modes af et venligt stemt folk. Deres frygt viser sig at have veret ubegrundet, idet den gamle konge allerede er dod. Folket - efter det har fäet hele historien - er kun lykkeligt over, at der allerede er fundet en ny konge, som i virkeligheden er kejserens datter.

Det afsnit, som jeg har valgt at kalde "mødet med den skaldede kronprins og hans besætning" 16 begynder med en præsentation af kronprinsen, som nærer et ønske, som tilhøreren/læseren genkender fra afsnittet om købmands- 
sønnen. Men Nahman ændrer denne gang billedet og gør det udpræget negativt, idet kronprinsen kvitterer for sin faders imødekommenhed med uansvarlighed og frivolitet. Kejserens datter, der "gender"-mæssigt nu er en mand, praler overraskende med sin kunnen over for sine mandsklædte hofdamer, gør nar ad kronprinsens mangel på hår ved at kalde ham "skaldepande" og dræber ham øjensynligt blot for at bevise sin påstand om, at han/hun kunne. I det forudgående er tilhøreren/læseren blevet vænnet til diverse amoralske og onde handlinger, som dog alle havde til formål at beskytte. ${ }^{17}$ Kejserens datter er $\mathrm{i}$ denne episode ikke tvunget til at komme $\mathrm{i}$ kontakt med kronprinsens skib. Hun vælger det selv og af den grund fremstår drabet af kronprinsen som en overraskelse. Jeg vil dog forsøge mig med en forklaring. Kejserens datter, som fremtrædelsesmæssigt er blevet mand, kan i den forbindelse have indoptaget en vis grad af maskulinitet. Til støtte for denne tese, som, må jeg indrømme, er yderst freudiansk, er, at kejserdatterens middel til drabet er en linse, som rettes mod et objekt. Funktionelt set er en linse ensbetydende med forlængelse af synet. Synet er fallisk af natur, idet det penetrerer et rum for at nå frem til sit objekt. ${ }^{18}$ Hvis vi på den ene side således har den mandsklædte kejserdatter med hendes falliske linse, så har vi på den anden side en umoden kronprins, der måske for at vise sin kunnen følger efter sine undersåtter i deres forsøg på at kravle op i skibets mast. Der er tale om to mænd, der begge er engagerede i praleri, og tilhøreren/læseren må spørge sig selv, hvorfor kejserens datter tager del i dette projekt. Hvis vi bliver i det freudianske, så er en mast yderst fallisk, og når kejserens datter venter med at vælte ham ned, indtil han har nået toppen, skabes i et glimt et skræmmebillede bestående af en person, der burde være forbillede, på toppen af et maskulint symbol. Med kronprinsen siddende $\mathrm{i}$ toppen af masten, demonstrerende sin kunnen og ophøjethed, kan tilhøreren/læseren med gysen se ind i fremtiden, hvor et land skal regeres af en uansvarlig, frivol og magtsyg mand. Enhver læser med kendskab til israelitisk-jødisk religion ved, at en dårlig konge kan trække misvækst og ufrugtbarhed ned over sit land. Kejserens datter er trods sit "gender"-skifte stadig i forbindelse med de beskrivelser, der tillagde hènde fællestræk med Shekhinah, dvs. beskrivelser, hvor hun potentielt set var kanal for de guddommelige energier og Guds vilje. Der er intet i vejen for, at kejserens datter nu som mand stadig står $\mathrm{i}$ en højere magts tjeneste og derfor straffer den umodne kronprins for ikke at leve op til sit ansvar som kommende beskytter af et folk. For at undgå ufrugtbarhed må kronprinsen dræbes. Det er et patriarkalsk system over for et andet patriarkalsk system, og derfor anvendes de falliske symboler - et system, hvor israelitisk-jødisk religions patriarkalske Gud sikrer frugtbarhed omend ondskab skal tages i brug som middel mod det andet systems magtsyge og uansvarlige ledere, som forretter misvækst. ${ }^{19}$ 
Afsnittet afsluttes med en beskrivelse af den skaldede nu afdøde kronprins' kujonagtige besætning og af, hvorledes kejserens datter i mandsdragt indvilliger i giftermål med kronprinsessen. Giftermålet kunne beskrives som et homosexuelt bigamistisk projekt, som ikke er moralsk forsvarligt i israelitiskjødisk religion. Men set fra kejserdatterens side kan giftermålet legitimeres, idet hun som kommende konge kan styre begivenhedernes gang ud fra sin indsigt og ud fra den plan, som tilhøreren/læseren kun kan håbe på, at kejserens datter handler udfra.

\section{Slutningen på fortellingen (Band: 77,5-78,10)}

Slutningen på hele fortallingen indledes med en passage, hvor sidste del af kejserdatterens sandsynlige plan nu kan anes. Kejserens datter er blevet konge og inviterer alverden uanset status og rang til sit bryllup og lover alle store gaver. Desuden beordrer hun fontener bygget $i$ bele byen, således at alle kan fá slukket deres torst med det samme. Hun beordrer sit billede ingraveret på bver fontene, og en vagtpost skal stå for at se, om nogen skulle rynke panden pga. billedet; i så tilfalde skal vagtposten kaste vedkommende i fangsel. Alle tre mand, som bun mere eller mindre indgik agteskab med, dukker op, genkender noget ved bendes billede og fyldes med sorg. Vagtposterne gor deres pligt og sender dem $i$ fangsel. Under brylluppet bliver de tre fanger fort for kejserens datter, som de imidlertid ikke genkender pga. hendes mandsdragt. Kejserens datter tager ordet og giver den ugifte konge sine elleve hofdamer tilbage med en opfordring til dem om at gå hjem. Til den eksilerede kobmandsson giver hun hans skib tilbage, og som kompensation for hans lidelser og tab fair han ligeledes alle rovernes tyvekoster, som kejserens datter bavde bragt ombord. Endelig henvender hun sig til den mand, der har veret skilt fra hende, lige siden ringen blev glemt $i$ skoven. Hun kalder kongesonnen til sig og opfordrer til, at også de sammen skal gå hjem.

I sin nye position som konge er kejserens datter endelig i stand til at dominere begivenhedernes gang uden indblanding fra andre. I den forbindelse er det værd at bemærke, at i fortællingens afslutning kommer ingen anden til orde end kejserdatteren selv. Vel reagerer vagtposterne men kun efter kejserdatterens ordre. Første træk i den endelige udfoldelse af planen er at invitere alverden til sit og kronprinsessens bryllup, og alle loves store gaver i invitationen. Tilhøreren/læseren kan være i tvivl om, hvorfor alverden inviteres. Er det for at lade alle være vidne til ægteskab med den skaldede kronprins' enke, eller er det, for at kejserens datter blandt alverden kan fă øje på sin forsvundne ægtemand? Det er højst sandsynligt det sidste, idet den indledende ramme for fortællingen omhandlede kongesønnen og kejserens datter, og læseren nu 
befinder sig i slutningen af fortælleforløbet og derfor kan forvente, at rammen dukker op igen. Når alverden desuden loves store gaver, er gaverne næppe tænkt som belønning for at deltage i brylluppet med enken; de skal nok nærmere fortolkes som symboler, der peger frem mod den overflod og rigdom, der vil blive resultatet af kejserdatterens plan.

Et andet overflodssymbol, der præsenteres på dette tidspunkt i fortællingen, er fontænerne. De skal opstilles, således at ingen skal tørste. Men udover at have en rent tørstslukkende funktion refererer fontænerne pga. det flydende vand til sefirotsystemet og dets flydende guddommelige energier. Sefirotsystemets vigtigste funktion kan siges at være at kanalisere Guds vilje og Guds livgivende næring ned til Guds skabninger. Når de guddommelige energier således flyder, så slukker de ikke kun tørst, de er altafgørende for liv og frugtbarhed, idet det er Guds intention med skabelsen, og deres falliske funktion er åbenbar. Men frugtbarhed som konsekvens af sefirotsystemets fritflydende energier er kun en mulighed, hvis den feminine sefirah Shekhinah og den maskuline sefirah Tif'eret bliver forenet. De to sefirots forestående forening er imidlertid lige præcis det, der indikeres, når kejserdatterens billede ingraveres på de opstillede fontæner. Kejserdatterens ingraverede billede er det litterære billede, der peger frem imod, at hun som Shekhinah vil genindfinde sig på sin plads i sefirotsystemet efter at have været tvunget til at forlade denne beskyttede position for at genetablere forbindelsen mellem hende og den forsvundne kongesøn. Hvis man samtidig retter blikket mod Shekhinahs rolle i forbindelse med menneskeheden, så er det hendes opgave at straffe og belønne menneskeheden, således at den erkender Guds vilje og følger den. Hendes arbejde ér $t i k k u n^{20}$, og uden det vil verden aldrig blive rede til forløsning. Når Shekhinah indfinder sig på sin plads i sefirotsystemet, er det således udtryk for, at menneskehedens opførsel tillader hende at modtage guddommelig energi fra Tif'eret. Hvis menneskehedens opførsel gik imod Guds vilje, ville Tif'eret straffe hende for menneskehedens synder, idet menneskene betragtes som Shekhinahs børn og ansvar, og Shekhinah ville være forment adgang til den beskyttede plads i sefirotsystemet. Fontænernes funktion som litterært billede bliver således ved at vise tilbage til idealtilstanden $i$ sefirotsystemet i den nye kontekst at informere om, at forløsningen er nært forestående.

Fontænernes umiddelbare funktion i fortællingen er ikke at forglemme dog for kejserens datter at få kontakt til hendes oprindelige ægtemand og desuden til købmandssønnen og den ugifte konge, som begge måtte lide på hendes vej til hendes nuværende position. Fontænerne virker som ønsket, og alle tre mænd bliver bragt for kejserens datter, som de ikke kan genkende, fordi hun er klædt som mand. Købmandssønnen og den ugifte konge får 
godtgjort deres tab. Kejserens datter som Shekhinah, Guds tilstedeværelse, viser ved sin tilbagebetaling, at mennesket tilfældigt kan blive offer for Guds nødvendige omend uransagelige gerninger, men tiden vil vise, at Gud er retfærdig. Tilbagebetalingen kan således for den hasidiske tilhører/læser blive udtryk for et stort håb. At slutningen på fortællingen intet nævner om røverne og den skaldede kronprins, må tages som udtryk for, at den skæbne, de led, var velfortjent. Besærningen og kronprinsessen erfarer tilhøreren/læseren heller intet om. Det tolker jeg på den måde, at slutningen, hvor kejserens datter bliver forenet med sin kongesøn, bliver den skaldede kronprins' besætnings straf for kujonagtig adfærd og villighed til kongemord. De mister en konge og har gjort sig selv til grin, den dag de opdager kejserdatterens sande køn. Nahman har således ikke ladet det forblive ukommenteret, han har bare ladet tavsheden og ironien tale. Uden at give sin kvindelighed til kende henvender kejserens datter sig til sin elskede kongesøn og opfordrer ham til sammen med hende at vende hjem. Hvor "hjem" er, får læseren ikke at vide. Kejseren og kongen kan i princippet stadig være i live og være lige modvillige over for det ægteskab, som de i sin tid fik planlagt som del af et løfte. Derfor skal forståelsen af ordet "hjem" nok findes et andet sted.

\section{"HJEM" SOM UDGANGSPUNKT FOR EN FORTOLKNING}

For at kunne fremlægge min forståelse af ordet "hjem", må jeg anvende en skitse, som samtidig er en illustration af fortællingens struktur, dynamik og disses værdiladninger. Den har til formål dels at illustrere min fortolkning, dels at synliggøre fortællingens brug af $\mathrm{k} ø$ n. Skitsen fokuserer på fortællingens og figurernes udvikling fra og med adskillelsen efter tabet af ringen.

"KONGESøNNEN"'s rolle i fortællingen efter "ADSKILLELSE" kan aflæeses i skitsens venstre side, der vertikalt beskriver udviklingen fra "negativ passivitet" over "retfærdighed og genforening" til "FORENING OG BALANCE".

Udviklingen hos "KEJSERENS DATTER" er ligeledes et resultat af "ADSKILLELSE" og

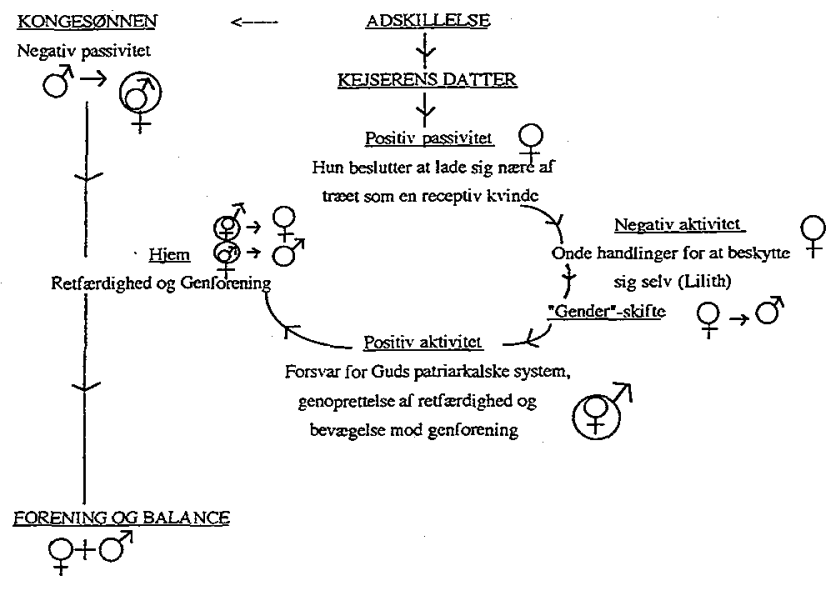
beskrives cirkulært i punkter med angivelse af køn og værdiladninger midtfor 
i skitsen. Kejserens datter og kongesønnen forenes ved punktet "Hjem" i venstre side, og sammen bevæger de sig til fortællingens afslutning, der er "FORENING OG BALANCE".

Grunden til, at jeg ikke kan betragte fortællingens første rum (Band: 67,I$68,25)$ som de elskendes hjem, er, at det rum er udfoldelsessted for en bestandig kamp mellem på den ene side tilfældet, der har et særdeles guddommeligt skær og fædrenes manifestation af egensindig vilje på den anden side. Eftersom intet i fortællingen ændrer fædrenes indstilling, må den i princippet stadig gøre sig gældende, og deres indstilling til kejserdatterens og kongesønnens forening vil på ingen måde kunne danne ramme for de elskendes hjem. De elskendes flugt må derfor betragtes som værende endegyldig, og i slutningen af fortællingen er der intet, ud over kejserdatterens og kongesønnens tilstedeværelse, der dukker op fra den indledende ramme, som kunne ændre på denne opfattelse. Flugten, der blev muliggjort af tilfældet, der lod dem mødes i kejserens palads, bliver fædrenes straf, idet de hver især mister deres arvefølge. Flugten giver kun de elskende knapt et døgns samdrægtighed, førend glemsomheden sætter ind og medfører tabet af symbolet på deres kærlighed og forening. Adskillelsesperioden begynder, hvilket samtidig bliver indledningen til den proces, der skal føre dem sammen igen.

Jeg har valgt at betegne kongesønnens reaktion på adskillelsen som "negativ passivitet". Med ordet "negativ" mener jeg ikke, at hans adfærd er skadelig, men hans reaktion er på ingen måde frugtbar. Han er gået under sin stand og har placeret sig i en meget kvindelig rolle, idet der fra ham som tjener med den udsigtsløse konstatering af, at han intet kunne gøre og derfor blev tjener, ikke kan forventes nogen form for initiativ. Da kongesønnen på den anden side heller ikke er kvinde, kan han ikke forventes at åbne op og modtage på samme måde som en kvinde for at lade sig nære. Det ville være uværdigt for ham at lade sig nære af en anden mand. Derfor bliver han sat til side i fortællingen, hvor eneste fremtidsudsigt må være håbet om, at hans kvinde, kejserens datter, kan ændre på hans tilstand.

Kejserens datter reagerer i første omgang tro mod sin kvindelige natur og lader sig nære af frugttræerne, dvs. naturen, og søger beskyttelse i et træ, som må betragtes som værende selve sefirottraet. Nahman lader således et ældre, kabbalistisk billede indgå i fortællingen. Både placeringen af hende i dette ene træ og Nahmans ordvalg taler for, at kejserens datter er billede på Shekhinah. Jeg betragter kejserdatterens reaktion på adskillelsen som "positiv passivitet", idet hun ved at åbne op for, hvad naturen og sefirottraet kan give hende, lader sig styrke samtidig med, at hun vogter den dyd, som er lovet væk til kongens 
søn i ægteskab. Det vil sige, at hendes opførsel er udtryk for en tro på genforening. Hun har desuden placeret sig på et sted, hvor forbipasserende kan påvirke hendes situation. Hun har åbnet op for, at en udvikling kan finde sted. Denne form for passivitet er kun mulig og kun positiv, fordi kejserens datter er en kvinde.

Kejserens datter bliver imidlertid revet ud af denne beskyttede og livsnærende position, da købmandssønnen, den ugifte konge og senere røverne tvinger hende ind $i$ et forhold til dem. Der er en vis magtdemonstration i det fra deres side, men kejserens datter undviger ved at acceptere med diverse betingelser for derefter at udføre onde gerninger for ikke at miste sin dyd til dem i ægteskab. Der er tale om en beskyttende form for ondskab, hvor hun værner om sin dyd på samme vis, som Lilith beskytter Shekbinab i Sefer haZohar (Se Sefer ha-Zohar II, I08b, I, I5Ib-I52a, III, 97a og III, 69a). Jeg vælger at betegne kejserdatterens handlinger fra Band: 70,6-74,I3 som "negativ aktivitet", idet død og ødelæggelse følger i kølvandet. Jeg mener også at kunne se en sammenhæng mellem ondskaben og den kendsgerning, at hendes handlinger absolut ikke er kvindelige (i.e. drikke folk fulde, forføre kvinder, stjæle skib og nedslagte mænd). Det er som om, at en kvinde bliver ond i jødisk mystik, når hun sprænger rammerne for de gængse opfattelser af, hvad kvindelighed er, fordi det frugtbarhedsideal, der gemmer sig overalt $\mathrm{i}$ israelitisk-jødisk religion, kun er opnåeligt, hvis kvinden accepterer sin rolle som receptor for den mandlige livgivende sæd. Det receptive er uforeneligt med aktivitet, og man ledes til at tro, at en kvinde automatisk bliver repræsentant for ondskaben, så snart hun griber til handling. Derfor må kejserens datter i disse afsnit (Band: 70,6-74,I3) betegnes som Shekbinahs alter ego, Lilith.

Efter nedslagtningen af røverne vælger kvinderne anført af kejserens datter at foretage et "gender"-skifte. Mandsdragterne gør kvinderne uigenkendelige som kvinder og forlener dem med en mandlig fremtrædelsesform. Om kvinderne også opfatter sig selv som mænd er mere tvivlsomt; dog er deres handlinger mandlige pga. det aktive, og siden kejserens datter giver udtryk for at være parat til at gifte sig med en anden kvinde, berøres selvforstålsen til en vis grad. Fra og med "gender"-skiftet udvikler fortællingen sig mere målrettet, og kejserdatterens handlinger kan ved nærmere undersøgelse betegnes som "positiv aktivitet". Drabet på den skaldede kronprins viser sig ifølge min tese at være forsvar for det israelitisk-jødisk patriarkalske system. Kejserdatterens vej til tronen og valg til konge muliggør, at hun kan genoprette retfærdigheden og endelig, at hun kan arrangere, at hun og kongesønnen bringes sammen igen. Med et mandligt ydre er kejserens datter i stand til at forene sig med kongesønnen. Metamorfosen, hvor kejserens datter opnår et mandligt ydre, muliggør de genoprettende handlinger og hjælper tilhøreren/læseren til at tolke død 
og ødelæggelse positivt, idet død og ødelæggelse som aktive handlinger udføres af en figur med et maskulint ydre.

Den sidste metamorfose, som tilhøreren/læseren ikke hører om, gemmer sig i opfordringen til, at kejserens datter og kongesønnen sammen skal gå hjem. Hverken kejserens datter eller kongesønnen befinder sig i deres hjem, og det er derfor oplagt at hæfte betegnelsen "landflygtighed" på deres eksistens. Vender man sig mod Tanakh'ens syn på det at vende hjem fra landflygtigheden, konnoteres en tilbagevenden til Jerusalem. Når Israels folk vender hjem, vender Jahve samtidig hjem, hvilket er ensbetydende med genoprettelse af pagten (Se Jes. 52,8 og Zak. 8,3). Disse associationer til Tanakh'ens syn på hjemvendelsen kan hjælpe tilhøreren/læeseren til en forståelse af både kongesønnen som litterært billede i samspil med ordet "hjem". Kejserdatterens opfordring til kongesønnen, om at de sammen skal vende hjem, bliver Guds invitation til Israels folk om at genoprette den pagt, der udelukkende bygger på Guds kærlighed og velvilje. Invitationen er en tilgivelse af folket, der muliggør, at kongesønnen kan træde ud af sin tjenerrolle og blive Guds elskede. I Tanakhen ses, hvorledes Israel kun i et ideelt forhold til Gud kan bevare sin suverænitet over for landets omkringliggende stormagter. Har stormagterne overherredømme over Israel, tvinges landet til passivitet og tilbagetrukkenhed (jvf. f.eks. Jes. 42,22-25). Knesset Israel, det sande/ideelle Israel, er i jødisk mystik et delaspekt af Shekhinah, ${ }^{21}$ således forstået, at Knesset Israel kun eksisterer, når folket afstår fra synd, lever i overensstemmelse med Guds vilje, og når Shekbinah befinder sig på sin beskyttede plads i sefirotsystemet. $\mathrm{Da}$ The King and the Emperor netop skildrer Shehkinahs kamp mod sin egen ubeskyttethed og mod verdens synd, kan kongesønnen ikke optræde i hovedparten af fortællingen. Kongesønnen er ligesom Knesset Israel afhængig af folkets måde at leve på og af Shekhinahs indgriben. At folkets levevis bevæger sig $i$ en ideel retning, angives i fortællingen ved, at de elleve hofdamer underordnes kejserens datter. Sammen tolker jeg de tolv kvinder som et billede på Israels tolv stammer, ${ }^{22}$ og at de lader sig lede af kejserens datter, der besidder den guddommelige indsigt, peger frem mod aktiveringen af Knesset Israel. En litterær genbrug af forestillingen om det sande Israel i modsætning til det konkrete Israels folk bygger på profetlitteraturen. Jesaja 6,9-13 kan have været afgørende. En rest af Israel skal bevares, fordi den har omvendt sig til troen på Jahve og til Gudsfrygtig adfærd i modsætning til den forhærdede del af folket. Hos Jeremia 31,27-33 følger en ny pagt mellem Jahve og den del af folket, der overlevede de ødelæggelser, som Jahve sendte med det formål, at enhver skulle dø for sin synd. At det sande Israel/Knesset Israel samtidigt som litterært billede kan forstås som delaspekt af Shekhinah skyldes sandsynligvis idéen om Herrens tjener, som den fremstår bl.a. hos Jesaja 42,I-7, hvor der står: "... Jeg 
danner dig [Herrens tjener] og gør dig til en pagt med folket, til et lys for folket. ${ }^{23}$ Her er det Herrens tjener, der dels symboliserer pagten med folket, dels forudgående skal bane vejen for folkets omvendelse. Et samspil mellem kejserens datter, kongesønnen og ordet "hjem" lægger således op til den udlægning, at fortællingen drejer sig om foreningen mellem. Guds tilstedeværelse og det ideelle Israel. ${ }^{24}$

Hvad angår den endelige udlægning af ordet "hjem", er det på det mystiske plan vigtigt at notere sig, at "hjem" er det sidste ord i fortællingen. "Hjem" er ligeledes det sidste skridt tilbage mod kejserdatterens og kongesønnens oprindelige køn. Når kønsbalancen er blevet genoprettet, kan kvinde og mand igen forenes. Den naturlige kønsrollefordeling er i jødisk mystik billede på det ideelle forhold mellem Shekhinah og Knesset Israel, som igen er forudsætningen for, at frugtbarheden kan eksistere. Frugtbarhed er altafgørende for liv, og liv er den velsignelse, der følger, når foreningen mellem Guds tilstedeværelse og det ideelle Istael finder sted, og liv var Guds intention med skabelsen.

\section{KonKLUSION}

Med udgangspunkt i teserne om, at Nahmans anvendelse af køn refererer til det kønnede sefirotsystem, at anvendelsen af køn afspejler Nahmans religiøse budskab, og endelig at protagonisten $i$ The King and the Emperor, i.e. kejserens datter, gennem sin tale og sine handlinger konstitueres som Nahmans talerør, valgte jeg en litterær, kønsreflekteret metode til at efterprøve mine tesers adækvans. Min litterære, kønsreflekterede metode lagde op til et fokus på dels genbrug af religiøst billedsprog, dels på et åbent billedsprog, der nødvendiggjorde tilhørerens/læeserens engagement $i$ velkendte figurers placering $i$ en ny og tvetydig kontekst, og dels de litterære figurers aktivitetsgrad og værdiladninger set $\mathrm{i}$ forhold til deres køn. Tilgangsvinklen havde som konsekvens den centrale problemformulering: Hvordan kan kejserens datter både fungere som Nahmans protagonist og dermed talerør, når hun ved sine handlinger i løbet af fortællingen afviger fundamentalt fra den ideelle rolle, som tilskrives feminine figurer i jødisk mystik?

I forhold til den centrale problemformulering kan det noteres, at kejserens datter opfører sig ideelt i fortællingens første og sidste afsnit. I de fire mellemliggende afsnit (jvf. min inddeling), der skildrer adskillelsesperioden, bliver tilhøreren/læseren vidne til kejserdatterens tyveri, falske løfter, hvorledes hun bringer andre i ulykke, hendes homosexuelt konnoterede bortførelse af hofdamerne, hendes løgne og misbrug af Guds navn, hendes aflæggelse af det 
køn, Gud gav hende, drab og endelig et forestående homosexuelt bigamistisk ægteskab. At kejserens datter på trods af dette omfattende syndsregister kan forbindes til Shekhinah, skyldes dels det første afsnit, hvor Nahman ved at lade hende trække sig tilbage i træet, vækker en stærk konnotation til den tiende sefirah, der er billede på Guds tilstedeværelse. Dels skyldes det, at kejserdatterens syndige adfærd ledsages af en beskrivelse af hendes musik- og sprogkundskab. Udover at musik og sprog afspejler indsigt i Guds vilje, er det samtidig fænomener (se note 13 ), der associeres til den beskyttende ondskab i jødisk mystik. Den beskyttende ondskabs mest kendte repræsentant er Lilith, som er det alter ego, Shekhinah fremviser, når et syndigt Israel skal konfronteres med ondskab med det formal, at Israels folk retledes, således at Shekhinah ikke bestandigt formenes adgang til sefirotsystemet og den befrugtende forening med Tif'eret. Musik og sprog er således de markører, der hjælper tilhøreren/læseren til at kunne forholde sig til kejserdatterens afvigelser fra den ideelle feminine rolle og til at se den syndige adfærd som bestående af nødvendige handlinger, der skal genoprette pagtsforholdet mellem Shekhinah og Knesset Israel.

Et overordnet formål med denne artikel var at påvise frugtbarheden af at forstå Nahmans brug af køn set i forhold til de litterære figurers aktivitetsgrad og værdiladninger. Vigtigt har derfor været den observation, at kejserens datter først blev associeret med negativitet på det tidspunkt i fortællingen, hvor hun blev tvunget til aktivitet efter at have forladt sin beskyttede position $\mathrm{i}$ træet. Den negative aktivitet forvandledes imidlertid til positiv aktivitet fra og med drabet på røverne og det efterfølgende "gender"-skifte. Med et maskulint ydre forhindrede hun en uansvarlig kommende regent $i$ at trække misvækst ned over hans land og sikrede samtidig med sin opsøgende aktivitet, at hun og kongesønnen kunne vende tilbage til deres respektive køn. Efter genetableringen af kongesønnen som mand tolker jeg ham som billede på et Israel, der kan markere sig aktivt og selvstændigt $\mathrm{i}$ verdenssamfundet pga. den velsignende frugtbarhed, som det modtager gennem pagtsforholdet. Kejserens datter, hovedperson og nøgle til en forståelse af fortællingen, udlægger jeg i hendes passive feminine rolle som receptor for de guddommelige energier, der flyder til hende fra den maskuline sefirah Tif'eret gennem sefirotsystemet, og dermed som Shekhinah med den sefirahs både barmhjertige og dømmende sider. Nahmans fortælling afspejler således, hvordan Nahman ved hjælp af køn og genbrug af religiøse litterære billeder formidler et budskab om den nødvendige konflikt, retledning af folket og anvendelse af negativ adfærd, der skal sikre pagtsforholdet og dermed landets frugtbarhed. At Nahman overhovedet kan formidle dette budskab, skyldes hans åbne billedsprog, hvor han ved at trække på kønskonstruktioner fra Tanakh’en og Sefer ha-Zohar og ved at 
placere disse i en ny kontekst tvinger tilhøreren/læeseren til at associere både det israelitiske og det kabbalistiske frugtbarhedsideal med hans egne lirterære figurer og billeder, for at hans brug af køn overhovedet kan give mening. Nahmans brug af køn afspejler således ikke hans fabulationer, således som den biografiske forskning har indikeret (Band: 290). Fortællingens skjulte indhold er dybere, som artiklens indledende citat angiver, omend jeg langt fra har kunnet berøre alle detaljernes betydning.

\section{Noter}

I. Citatet stammer fra Bratslav-hasid'en Nahman fra Cheryns kommentar til The King and the Emperor. Her citeret efter Green: 353; $37 \mathrm{I}$ n. 18.

2. Den første udgave af Sippurey Máasiyot var tosproget - på jiddisch og hebræisk. Nahman-forskningen har ikke med sikkerhed kunnet fastslå, på hvilket sprog fortællingerne oprindeligt blev fortalt, men det synes at være en generel antagelse, at Nahman fortalte dem på jiddisch.

3. I denne artikel refereres der til den meget roste engelske oversættelse af fortællingerne, der blev foretaget af Arnold J. Band i 1978 med titlen Nabman of Bratslav - The Tales. Det skyldes, at den tosprogede version på jiddisch og hebræisk ikke er tilgængelig i Nordeuropa, og at min læser dermed ikke ville have mulighed for at forholde sig til min udlægning.

4. Mendel Piekarz har desværre ikke analyseret The King and the Emperor, men hans kritik af den meget biografiske tilgang til Nahmans fortællinger er at finde i Hasidut Bratslav, Jerusalem, 1972.

5. Peter S. Paludan gør f.eks. i sin artikel fra I990 "Merkavah-mystikken: Den ældste jødiske mystik" (Bilde og Geertz: Mystik - den indre vej, Århus, 7I-92) opmærksom på, hvorledes mystikken gradvist opstod som de tidlige rabbineres udlægning af ældre tronvisioner og himmelrejser, som de beskrives i forbindelse med israelitisk-jødiske fortidsskikkelser som Enok, Daniel og Ezra.

6. Disse refleksioner over billedsprogets funktion blev præsenteret af Kirsten Nielsen i hendes teologiske doktordisputats For et tre er der hab. Om treet som metafor i Jes. I-39 fra 1985 .

7. Se ligeledes Kirsten Nielsen: Bilderna och Ordet-Om Herrens tjänare och andra bilder $i$ Gamla testamentet, Libris, Örebro, 1998: 29-32.

8. Jvf. Phyllis Trible: Rhetorical Criticism - Context, Method, and the Book of Jonah, Fortress Press, Minneapolis, 1994: IOI-I06.

9. Se Gen. 16,4f; I. Sam. 1,6; Jer. 15,7; Ez. 5,17 og Hos. 9,12 for Tanakh'ens syn på barnløshed. I jødisk mystik lukkes Shekhinahs underliv, hvis folket synder. For at åbne det igen må ondskaben i form af Lilith først næres, så hun kan straffe folket for dets synder, førend Shekhinahs underliv igen kan åbnes. Shekhinahs åbne underliv er udtryk for, at hun med de guddommelige livgivende energier fra Tif'eret, der flyder til hende og igennem hende, kan bringe frugtbarhed til Israels folk (Se Sefer ha-Zohar III, 249a-249b). Disse konnotationer, som barnløsheden rummer, giver mig grund til at tro, at Nahman med kongens og kejserens barnløshed ønsker at understrege, at samfundets ypperste repræesentanter har syndet og dermed ikke gjort sig fortjent til den gave, som frugtbarheden er. Yeshivat Chasidei Breslov (de religiøse Bratslav-hasidims eget institut) i Jerusalem har under ledelse af Rabbi Aryeh Kaplan udgivet en annoteret oversættelse af Nahmans fortællinger. I den udlægges kongen 
som sefirab'en Binah og kejseren som sefirab'en Hokbmah, hvilket som konsekvens bør have en positiv forståelse af kongen og kejseren. Men jeg mener ikke, at Kaplans udlægning tager højde for, at kongen og kejseren ikke dukker op i fortællingens ellers så lykkelige slutning, hvor de burde indfinde sig, hvis de var så positive figurer, som Kaplan hævder. Jvf. Aryeh Kaplan: Rabbi Nachman's Stories, the Breslov Research Institute, Jerusalem, I983: 55.

ro. Positive løfter, hvor man stiller Gud tilbedelse og ærefrygt i udsigt, går under betegnelsen neder. Der er i Tanakb'en adskillige eksempler på disse, men det mest interessante i denne sammenhæng er Hanna i r. Sam., der afgiver et løfte til Gud for at fă en søn. Yderligere, fordi der er tale om løftebrud hos royale, vækkes associationer til live til Faraos utallige løftebrud til Moses og Israels folk, da de ønskede at forlade Ægypten. Faraos løftebrud betød, at Israels folk ikke kunne blive forenet med det land, som Gud havde udset til sit folk (Ex. 5-I4). Som GDB I98I skriver om "løfter", rykker de op på et ukrænkeligt hellighedsplan, og i og med at kongens og kejserens forudgånde barnløshed kunne være udtryk for begået synd, så støtter det min tese om, at kongen og kejseren indgår deres løfte med Guds straf hængende over hovederne. Konnotationen til udfrielsen fra Egypten er interessant, jvf. sky- og ildsøjlen, idet den hjælper tilhøreren/leseren til at gennemskue, hvad kongesønnens og kejserdatterens forening symboliserer. Der gives en hentydning til, at fortællingen kan handle om, at Guds tilstedeværelse skal bringes ned over Israel.

II. Jvf. Nahmans andre fortællinger og legender om $\mathrm{Ba}$ al Shem Tov.

12. Købmandssønnens eksilering er sikret en forståelse hos Nahmans oprindelige, jødiske tilhører/læser, da han eller hun utvivlsomt har oplevet eksil som et konstituum ved tilværelsen.

13. Se Green: 138-139. Rabbi Aryeh Kaplan angiver som Bratslav-hasid, at musik skal forstås som det middel, hvormed Shekhinah kan kommunikere med kelippot - de skaller, der bl.a. med ondskab forsvarer Shekhinah ved at ligge omkring hende i et beskyttende lag. Sprogkundskab er vigtigt over for syndige nationer som f.eks. Babylon, der pga. fortidens oplevelse af sprogforvirring nemt kunne lade sig dupere af sprogkyndighed. Musik og sprog bliver således redskaber til at konfrontere ondskaben. Kaplan: 65 .

14. Som basis for kvindens truede dyd som litterært billede se Kirsten Nielsen: "Kvindens stilling i Det gamle Testamente": 69-9r i Thi Gud er jeg, ikke mand - Studier over kvindebilleder i Det gamle Testamente, red. Hansen \& Madsen, TF-tryk, Århus, I98I.

I5. Det danske sprog mangler en oversættelsesmulighed for det engelske "gender". "Gender" dækker både over den ydre fremtrædelsesform og den pågældendes selvforståelse. Som det vil blive tydeligt i min udlægning af fortællingen er det ikke kejserdatterens deciderede køn, der berøres ved metamorfoserne, det er hendes ydre og hendes handlinger.

16. Skaldethed kan, hvis man vælger at læse The King and the Emperor så sexuelt som det jødisk-mystiske univers nu tillader det, være en henvisning til corona på penis. Corona er det blottede stykke hud, der fremstår på penis efter omskærelsen, og er i kraft af sin runde form et feminint symbol, der gør det muligt for den mandlige mystiker at agere kvinde ved et samleje med Gud. I forbindelse med min udlægning af The King and the Emperor skulle kronprinsens skaldethed i så fald være receptor for den mandsklædte kejserdatters sæd, som er dødbringende, fordi kejserdatteren/Shekhinab må anvende ondskab og død over for den skaldede kronprins, fordi han ellers ville forrette misvækst i sit eget land. Grunden, til at jeg ikke lader denne tese indgå i min udlægning er, at det ville kræve en grundig og kritisk gennemgang af professor Elliot R. Wolfson's udlægninger af corona - se bl.a. 275n, 362n, 363,392,395 og 396-397 i Through a Speculum that Shines fra 1994 og arriklen "Woman The Feminine as Other in Theosophic Kabbalah", I87-I88 i The Other in Jewish Thought and History fra 1994.

17. Om Lilith som Shekhinahs beskytter se Sefer ha-Zohar I, IsIb-I52a; III, 97a, III, 69a og Sefer ha-Zohar II, ro8b. 
I8. Jvf. ligeledes Jean-Paul Sartres opfattelse af synet.

I9. Deut. 28,53 ff; Lament. 2,II 8 20; 4,9; 5,I0; Ex. xO; Hosea 2 og x. Reg. I7 f.

20. Tikkun kan udlægges som reetablering af ur-enheden i kosmos og Gud, hvor mennesket i sidste instans forenes med Gud. Tikkun forudsæetter, at alle menneskers guddommelige gnister skal løftes op fra den syndige eksistens, som gnisterne i sin tid blev fængslet i pga. tsimtsum - den skæbnesvangre sammentrækning i Guds væsen, der gav plads til ondskaben. Kun en bærer af den messianske sjæl kan udføre den endelige tikkun-handling, og i Nahmans teologi tolkes Shekhinah som Mashiah ben David, se Green: 186-189.

21. Se Tishby's kommentar i Lachower \& Tishby: 327; 381 og Scholem 1953: 50-5I.

22. Kejserens datter er i så fald repræsentant for den davidiske slægt, da det er hende, der i fortællingen genopretter foreningen, og idet det er Nahmans opfattelse, at Shekhinah er billede på Mashiah ben David (Green: I88).

23. Se desuden Jes. 49,I-I3; 50,4-II og 52,I3-53,I2 om den lidende Herrens tjener, der har paralleler til de lidelser, som Shekhinah må gennemleve, når hun er udstødt fra sefirotsystemet.

24. Når der $i$ jødisk mystik er tale om forholdet mellem en mandlig og en kvindelig figur, vil man normalt forvente, at det drejer sig om Tif'eret og Shekhinah. At jeg ikke mener, at kongesønnen kan tolkes som Tif'eret, skyldes dels den udprægede passive og næsten negative rolle, han udfylder i fortællingen. Dels skyldes det, at vielsesringen er et oplagt symbol på pagten, fordi ægteskab og forholdet mellem Jahve og Israel begge er baseret på kærlighed; dels at kongesønnen i slutningen af fortællingen optræder side om side med købmandssønnen og den ugifte konge; endelig - og nok mit vægtigste argument - at kongesønnen tvinges ud i en feminin rolle, hvor han modtagende må afvente, at kejserdatterens aktivitet kan have den befrugtende virkning, at de forenes. Tif'eret er udpræget maskulin i sefirotsystemet og er kendetegnet ved sin besvangring af Shekhinah. Hvis Nahman havde haft Tif'eret i tankerne, ville jeg forvente en væsentlig mere positiv og maskulin beskrivelse af kongesønnen. Dertil kommer, at folket ligesom kongesønnen altid har været passivt og feminint i forhold til Gud og Shekhinah i jødisk mystik.

\section{LITTERATUR}

Band, Arnold J. 1978. Nabman of Bratslav - The Tales, Paulist Press, New York.

Beauvoir, Simone de. 1965. Det andet køn, Kbh.

Green, Arthur. 1992 (1979). Tormented Master - The Life and Spiritual Quest of Rabbi Nahman of Bratslav, Jewish Lights Publishing; Woodstock.

Irigaray, Luce. 1985. Speculum of the Other Woman, Cornell University Press, Ithaca. Irigaray, Luce. 1993. An Ethics of Sexual Difference, Cornell University Press, Ithaca. Kaplan, Aryeh. 1983. Rabbi Nachman's Stories, the Breslov Research Institute, Jerusalem. Lachower, F \& I. Tishby. 1989. The Wisdom of the Zohar, Oxford University Press.

Leon, Moses de. I964. Sefer ha-Zohar, Mossad Harav Kook, Jerusalem.

Nielsen, Kirsten. I98I. "Kvindens stilling i Det gamle Testamente" i Thi Gud er jeg, ikke mand - Studier over kvindebilleder i Det gamle Testamente, red. Hansen \& Madsen, TF-tryk, Århus.

Nielsen, Kirsten. 1985. For et tre er der håb. Om treet som metafor i Jes $1-39$, København.

Nielsen, Kirsten. 1998. Bilderna och Ordet - Om Herrens tjänare och andra bilder $i$ Gamla testamentet, Libris, Örebro.

Scholem, Gershom G. 1974 (1946). Major Trends in Jewish Mysticism, Schocken Books, New York. 
Scholem, Gerschom G. I953. "Zur Entwicklungsgeschichte der kabbalistischen Konzeption der Schekhinah" i Eranos-Jahrbuch x952, Zürich.

Trible, Phyllis. 1994. Rhetorical Criticism - Context, Method and the Book of Jonah, Fortress Press, Minneapolis.

Wolfson, Elliot R. 1994. "Woman - The Feminine as Other in Theosophic Kabbalah: Some Philosophical Observations on the Divine Androgyne" i The Other in Jewish Thought and History. Constructions of Jewish Culture and Identity, ed. L. J. Silberstein og R. L. Cohn, New York University Press, New York.

Wolfson, Elliot R. 1994. Through a Speculum that Shines - Vision and Imagination in Medieval Jewish Mysticism, Princeton University Press, Princeton.

Wolfson, Elliot R. 1995. Circle in the Square - Studies in the Use of Gender in Kabbalistic Symbolism, State University of New York Press, Albany.

Wolfson, Elliot R. 1995. "On Becoming Female: Crossing the Gender Boundaries in Kabbalistic Ritual and Myth" i Gender and Judaism - The Transformation of Tradition, ed. T. M. Rudavsky, New York University Press; New York.

\section{Summary}

In this article, I approach the problem of understanding the emperor's daughter in The King and the Emperor by Nahman of Bratslav by exploring the literary imagery and characters which are gendered. Nahman's use of gender is no unique phenomenon in Jewish Mysticism. The sefirotic system e.g. is characterized by its male and female sefirot. In Sefer ha-Zohar the male sefirah Tif'eret and the female sefirah Shekbinah are depicted as the central figures whose sexual union is crucial since the creation of God depends on this union. Thus, gender is known to play a major part in Jewish Mysticism and a critique must be leveled against scholars who tend to explain Nahman's use of gender by referring to his delirious and maniodepressive periods and his problematic relationship to women. Their biographical approach is countered by my analysis of The King and the Emperor from the vantage point of the following three assumptions: Nahman's use of gender refers to the gendered sefirotic system. By applying the concept of the other and a focus on the valuation and the activity of the gendered characters it is possible to uncover the theological content of the tale. Finally, Nahman applies a literary imagery from the Tanakh and from the kabbalistic literature, thus, authorizing the message of the tale and at the same time forcing his listener/reader to engage in the imagery to be able to understand its formal meaning as well as its connotations. On the basis of this approach the emperor's daughter is interpreted as Shekhinah who uses every positive and negative means to further the union between Knesset Israel and herself as well as enabling her to withdraw to her receptive position in the sefirotic system from where she can bring fertility to God's creation. 